Phenomenology \& Practice, Volume 12 (2018), No. 2, pp. 15-27.

\title{
Vital Powers: Cultivating a Critter Community
}

\author{
Dr. Stephen J. Smith, Professor, Faculty of Education, Associate Dean, Faculty of Health \\ Sciences, Simon Fraser University \\ Email:stephen_smith@sfu.ca
}

\begin{abstract}
This paper is based on the eco-pedagogical aspiration to live with domesticated animals in accordance with Alphonso Lingis's Community of those who have nothing in common. I draw upon this remarkable text as well as Lingis's animal writings in describing moments and movements of pathic community. Such a community in affective affiliation with one another, where symbiotic relations are possible and bodily kinships are exercised, exemplifies what is possible in more rational human communities where domesticating impulses seek to harness the vital powers of coconstitutive life. Of telling significance are predatory threats, the manner in which they appear, and the protectionist responses they occasion. By recasting these threats and responses in terms of motional affordances, it may well be possible to move with non-human creatures, both literally and figuratively, beyond the anthropocentric confines of domestication. Animals with whom we appear to have nothing specifically, or in species terms, in common can show us how to cultivate more pathic communities of our own kind.
\end{abstract}

\section{Introduction}

Alphonso Lingis's animal writings inspire an ecological imagination of how we as a human species of metamorphic proportions have taken on the multiplicity of the flock, the school, the herd, and the pack. Our communal lives may at times appear of a mob mentality bound by animal drives, however there is contagious enthusiasm generated in particular group affiliations, feelings of solidarity that come with compelling community engagements, and a sense of belonging engendered when working alongside others for a common cause. These communal sensibilities have not necessarily left the flock, the school, the herd and the pack behind (cf. Welten, 2016, p. 132). Lingis (2007) reminds us that "[a]nimals come in packs, herds, and flocks, and induce multiplicity in the movements of the human animal who enters into symbioses with them" (p. 117).

In a paper titled "Ecological consciousness: Reflections on hominids and other thinking animals," Lingis (2001) wrote of the packs of wild dogs and prides of lions that prey upon the fleet-footed migratory herds of Africa. He cited anthropological evidence for understanding the evolution of human speech as that which distinguishes hominids from other animal species. Yet human speech remains linked to the "predator consciousness" of the hunting band (p. 294). The swimming, slinking, slithering, creeping, crawling, ponderous as well as light, fleet-footed, 
flapping, soaring movements of the multiplicity of predator and prey species may well have given definition to the water and land in, through, on, under, over, and around which these creatures move, however it is the human being with the definitional capacity of speech who has come to name and rule the land, oceans, and skies. Still, "predator consciousness" is not all we retain in affinity with other animals. There are also the cooperative and communicational manners resonating in human speech that pick up the "murmur of the world" (Lingis, 1994, pp. 69-105). We communicate amongst ourselves and potentially with other creatures in this coalescing, coconstitutive, confabulating "noise of life" (p. 92).

The quail and the albatross, the crows and the hummingbirds, the coyotes and the seals, the schooling fish and the great whales, the crocodiles infrasonically and the praying mantises ultrasonically continue and reverberate the creaking of the branches, the fluttering of the leaves, the bubbling of the creeks, the hissing of the marsh grasses, the whirring of the winds, the shifting of the rocks, the grinding of the earth's plates. (pp. 96, 97)

Conversation, dialogue, and the most deeply felt registers of communication amongst ourselves and with others still carry "the humming, buzzing, murmuring, crackling, and roaring of the world" (p. 84).

Lingis (2001) also points beyond this evolutionary, biospherical inheritance to suggest "that the human species is rapidly evolving into a species that lives entirely in an environment of its own making" (p. 298). In doing so, he poses the question of the connection between "this new ecological consciousness and the one that evolved in the savannah of East Africa four million years ago" (p. 299). Some indications of that connection are found in a later piece addressing the face of nature in the formative work of Emmanuel Levinas. Here Lingis (2010) draws attention to the moving, perceiving body that, since Maurice Merleau-Ponty's foundational phenomenological analyses, has been understood as contiguous with its situatedness in the world and, conversely, where the world is understood as the coefficient of corporeality. Incarnated subjectivity is "where we find ourselves within the sensuous medium, immersed in it" (p. 67). We sense that nature is essentially about movement. We see the plays of light, hear the vibrations of sound, taste and smell the flows of water and air, touch the oscillations of pressure and release. There are kinetic, kinesthetic, proprioceptive, and affective registers to the movements we perceive. Human sensibility carries the over-riding impression that "[n]ature is movement"(p. 79; also Lingis, 2011a, p. 40).

There is nothing necessarily new in this impression. What is noteworthy is the realization of the need for a "new ecological consciousness" that breaks with the evolutionary legacy of predatorprey dynamics yet finds itself still enthused by the energies of the pack, the herd, the swarm, the flock, and the school and by contact with the fish, reptiles, birds, and mammals whose motions we can see and feel reflected in our own movement repertoires. Lingis (2010) wrote:

To go to nature is to is leave sedentary and stabilized existence and enter into movement: moving with the falling leaves in the autumn winds in the mountains under the drifting or gathering clouds; moving through the savannah and the forest with the winds, ascending the mountains with the mists, drifting down the rivers; moving with the herds of wildebeests, zebras, and impalas in the Serengeti; soaring on a paraglider in the thermals with the vultures; or, not swimming, only steering with one's fins in the ocean surge with the coral fish. (p. 80) 
Going to nature means becoming animated by the movements of other creatures who compel us to not only recall from whence we came but also to remember how it is that we may stay affiliated with these creatures, symbiotically, and through the motional affordances of bodily kinship. Going to nature in this manner is not a movement backward in any kind of nostalgic feeling for what we domesticated human beings may have lost of our animal sensibilities, but a movement forward in eco-pedagogical appreciation of what our affective and motile relations with other creatures can teach us about how to live more vibrantly with one another.

I take up Lingis's animal sensibility as "an intelligibility that is affective before it is intelligible and vital before it is rational" (Sparrow, 2007, p. 110) and, specifically, as a motile, metamorphic impulse to participate in the community of those who have nothing in common (Lingis, 1994). I want to show that "the community of modern individuals that each one of us is born into - all of this is preempted by our encounter with other bodies, intruder or seducer bodies, and the appeals they make on our own" (Sparrow, 2007, p. 110). We sense these appeals at a primal level, at the level of sensation, through "the multiplicity in us - the human form and the nonhuman, vertebrate and invertebrate, animal and vegetable" (Lingis, 2000, p. 28). We respond in ways that reflect our creaturely composition and thus our capacity to move in diversely animated ways (cf. Serres, 2011, p. 51). In "each life extend[ing] across metamorphoses" (Lingis, 1998, p. 88; also Lingis, 2011b, p. 148), I assert that we can live more sustainably with one another through better appreciating the dynamics of life in a critter community where even those who have limited species characteristics in common can become motilely attuned to one another and, in doing so, create practices of communal living that are good for all.

Through my usage of the word 'critter' in preference to the more conventional 'creature' or 'animal,' I follow the lead of Donna Haraway $(2003 ; 2008)$ in challenging the division between human beings and other animals and suggesting, from the outset, that we are all critters with capacities to move with other creatures in deeply affecting and vitally empowering ways (Smith, 2017). I also have another purpose in mind that has to do with the colloquial sound of this dialectal variant of 'creature.' I want suggest that the essential features of a critter community are as much revealed in tone of voice as they are encounters in and of themselves. This suggestion follows from the comment made above, and attributed to Lingis, about the very evolution of human speech. It is, we might say 'critter-cally,' the very manner in which creaturely encounters are spoken of and written up that discloses their essential meanings. This, too, is why I have emulated Lingis's richly evocative, phenomenological descriptions and written this article, in significant part, as a "firstperson chronicling" (McLane, 2003, pp. 52-54; cf. Lingis, 2007b) of critter affiliation.

Focusing on interactions with domesticated farm animals, I have taken to heart the recommendation made by Scott Churchill (2006) that we extend the community sensibility Lingis articulated in his 1994 text and related publications "to include our relationship with animal others" (p. 9), albeit those of certain familiar kinds. My purpose in describing symbiotic relations, bodily kinships, and the motional affordances of pathic community for farm animals is to intimate an ecopedagogical sensibility that, in helping us better understand the interactions we have with domesticated animals and the interactions they have with one another, can have us better cultivate communities of our own kind. This "other community" (Lingis, 1994, pp. 1-13), in contrast with the "rational community" (p. 10; also Biesta, 2004), may well have no particular attribute or species characterization in common, however it contains movement possibilities and vital powers of "hetero-affective" affiliation (cf. Henry, 2008, 2015) that we can better cultivate within communities of our own kind. 


\section{Symbiotic Relations}

Today Sasha can be seen riding Joey in the back pasture. Well, if riding means one individual mounted upon another in some interplay of motional forces then Sasha the mop-topped chicken perched atop Joey the miniature horse must qualify. How she got up there or why Joey seems content to have her on his back is unclear. When let out in the mornings to forage though the gardens and venture into the open pastures, Sasha the Polish chicken, along with the Silkie Bantams and the fuzzy Frizzle chickens, appear as relieved to get away from Stanley the strutting, preening rooster and his hen-pecking consort Stella as the flock of Leghorns and Rhode Island Reds who lay the sellable eggs. Could Sasha have tired so much of the attentions of Stanley and Stella that she found a vantage point above all the feathered banter?

And what does Joey gain from having this passenger on his back? Perhaps the four-toed, little fowl provides a welcome scratch through the matted thickness of Joey's coat. Perhaps she is so light that her host hardly feels her presence. Or maybe Joey finds some comforting distraction from his laminitic hooves in Sasha swaying to and fro upon his back. Or could it simply be that Joey is as little attuned to Sasha as Rhinos are to Oxpeckers, Giraffes to Tickbirds, Braham cattle to Egrets, and even Crocodiles to Plovers where at least some of these larger creatures gain some clear benefit?

Over the next few weeks, Sasha and Joey seem to seek each other out. Sasha rides on Joey's back as he hobbles in at feed time, hopping down on the ground to peck at the grains of corn, barley and oats that spill from his bucket and, having had her fill, fluttering, flapping, cackling with enough effort to regain her perch upon his croup. Tasha holds tight when the full-sized horses come at a gallop and risk running over Joey and his miniature playmate Emily before they spin out of harm's way. She becomes accustomed not just to the steady rhythms of grazing but also to the bursts and rushes of energy that punctuate even this otherwise hobbled horse's days. It seems that Joey, were he to tire of Sasha's presence, could easily roll in the mud puddles, just as he is inclined to do when Sasha is not around.

A symbiotic relationship is cultivated between Sasha and Joey. We should not be too much concerned to define it in strictly biological terms as a kind of mutualism but to remember that symbiosis, before it became a word for organismic constitution and interspecies co-dependency, meant simply the sense of living together in the synergy of feelings for one another. Lingis (2003) takes up this original meaning of symbiosis while also acknowledging its biospherical breadth. He writes of our constitutive biology as a "symbiosis with thousands of species of anaerobic bacteria" necessary for organismic protection, food digestion, and absorption (p. 167). "We live," he says, "in symbiosis with rice, wheat, and corn fields, with berry thickets and vegetable patches," right down to "the nitrogen-fixing bacteria in the soil that their rootlets enter into symbiosis with in order to grow and feed the stalk, leaves, and seeds or fruit" (p. 167). Lingis then points out the symbiosis that is motoric, affective and visceral. He goes on to say that: "We also move and feel in symbiosis with other mammals, birds, reptiles, and fish" (p. 167; also Lingis, 2000, p. 27; and Lingis, 1998b, p. 195). Not only may "[o]ur legs plod with elephantine torpor," our movements attain a certain style when "decked out fashionably, we catwalk," carrying gestural energy when "our hands swing with penguin vivacity; our fingers drum with nuthatch insistence" and attaining an expressive grace when "our eyes glide with the wind rustling the flowering plants" (p. 167). These symbiotic, metamorphic motions retain vital contact with other species. 
In textual descriptions that must surely have been influenced by Deleuze's and Guattari's (1987) rendition of the intensities, valencies, and flows of "becoming-animal" (Neimans, 2007, p. 295), Lingis draws our attention to the surges, rushes, bursts, gushes, and flushes of energetic motion, and to the fadings, wanings, and stillings of bodily vigor, that resonate with the animal other. These upwellings and ebbings, these waves of excitation and washes of pacification, are always potential synergies of felt motions.

The woman who rides a horse lurches with the surges of its impulses, while the horse trots with her prudent programming. The movements of her body are extending differential degrees of speed and retardation, and feeling the thrill of speed and soothing decompression of retardation. These movements are not productive; they extend neither toward a result nor a development. They are figures of the repetition compulsion; one strokes a calf each night on the farm, one rides a horse through the woods with the utterly noncumulative recurrence of organism. (Lingis, 2003, p. 169)

Are we any closer to understanding the symbiotic relation that Sasha and Joey have cultivated? What synergies of feeling for one another might we infer in seeing Sasha perched repeatedly on top of Joey? Better still, what feelings of symbiosis enable us to put ourselves in Sasha's place, in Joey's place, and in the interstitial motions of riding and being ridden? Lingis suggests that "[w]e catch on to the urgent, the frantic, the panicky, the astonished tone....the snorting of the distrustful horse" (Lingis, 1998a, pp. 135, 136; also Lingis, 2005, p. 439). We also catch hold of the tonus of the trustful horse, this miniature pony who, for whatever reason or for no apparent reason at all, finds himself in close company with a chicken who has no better place to be.

"To live is to echo the vibrancy of things. To be, for material things, is to resonate" (Lingis, 1994, p. 96). As human beings with prefrontal cortex capacities of bringing sensibility to our senses, it is easy to overplay and thereby overlook this primordial resonance. Shall we find our ways back there through notions of attunement, mooded understanding, through empathy, sympathy, compassion, and care? Or might we go forward in acknowledging an essential "autoaffectivity" to life that is in keeping with a "pathos-with" others, which is to say, with an impressional "hetero-affectivity" (Henry, 2008, pp. 101-134)? And within this echoing, resonating, symbiotic affectivity, might we not also come to acknowledge the pathic basis to a sustaining eco-pedagogy?

Lingis (2011a) states that "[o]ur life is by nature destined to know life" (p. 89). He makes this claim by emphasizing particular life motions that reveal the metamorphic basis to the symbiotic relations we can have with other animals and which they appear to have with one another already. "We trot like horses," ride them, run with them, lead them, and follow their motions through our own meandering, wandering, foraging postures, positions, gestures, and expressions. "The one word we use-life - to characterize all of [these motions in common] indicates that our bodies deeply feel kinship with the bodies of other animate species" (p. 39). In describing now the motions of such kinship with a particular horse, I want to advance the intimation given up to this point of an eco-pedagogy that we may very well extend to relations with others of our own kind. 


\section{Bodily Kinships}

Can we come, in our bodily feeling for others, to understand the Chincoteague mare, Twilight, who rules the roost within this critter community of horses, llamas, ducks, chickens, quail, and rabbits? The miniature horses, Joey and Emily, try to keep out of her way yet are caught off guard when Twilight claims grazing rights to the paddock into which they amble. The Moscovy ducks flap and flutter to other locations or take refuge in the pond. The Indian Runner ducks, chickens, quail, and rabbits have bushes and brush to keep them safe. The skittish llamas keep a respectful distance. But the lunky, clunky Friesian gelding named Valentino is not so fortunate. He is bitten and kicked by Twilight on a regular basis. Twilight has no patience for Valentino standing between her and the grain and hay flakes thrown into the feeding trough. She runs at Valentino for little reason other than to make him move his feet. She chews his once luxurious mane and tail and leaves gashes on his withers and flanks for whatever slights she feels he deals her. Still, observing Twilight's more friendly interactions with Valentino and with the miniature horses, and watching her on occasion step nimbly around the menagerie of chickens, ducks, llamas, and rabbits without trampling the garden shrubs, we come to appreciate what Lingis might call a "noble body" comprised of "a combination of power, instincts, and extreme sensibility" (Zournazi, 2003, p. 92) and what this body might bring more regularly, more consistently, to this particular community of critters.

Twilight needs exercise. Her owner and I are worried that the nutrient-laden pastures at this time of year are too rich for her and may have her founder if she continues to carry so much body weight. We are also concerned that her pent-up energies are making her more domineering than usual. So, when I find her in the sand arena enjoying the splashes of sunshine one early Spring morning, it is a simple matter of closing the gate to stop her bolting back to the pastures and for me to have this time to put her through her paces.

Twilight tries to escape. She runs initially to the fence behind which Valentino is standing. She then tests the closed gate to see if it will yield. She could jump the arena fence if she really wanted but instead turns to face me. We stand eye-to-eye, face-to-face, body-to-body, although at some distance from one another. With simple arm cueing of movement direction and a bodily press for forward impulsion, I am able to send Twilight forward in a perimeter circle around me. She rapidly increases speed until she is racing flat out. Her steps are staccato soundings on the hardpacked surface of the arena. Her snorting breaths are short and labored. Her head is high, though not in the classical poll flexion that would have it suspended proudly from an impressively rounded neck connected to a tensioned, rounded backline. With her ears pinned back, the sclerotic whites of her eyes showing, and her tail between her legs, Twilight runs fearfully as if being chased by a predator. She runs and runs until I step toward and potentially into her line of flight in order to slow her motional panic and help her rebalance herself by shifting her weight backwards. Twilight's gallop shifts down to a canter. She can now lift herself with power coming more from her hindquarters than her forequarters. A little more bodily composure from me with deeper breaths drawn, and I have her gearing down further into a springy extended trot that has her forelegs and front hooves flicking out in front of her. I draw her closer by stepping backwards into the center of the arena. Twilight arcs around and toward me and may well run me over except that I follow her motions and press myself into them so that Twilight must bend away and outward to the perimeter of the arena. She now trots collectedly in a circular counter-direction.

Twilight's circling of the arena, with changes of pace and direction, becomes choreographed through the relational dynamics of contraction and extension, attraction and repulsion, pulling and 
pushing, drawing and sending. We communicate posturally, positionally, gesturally, and expressively in the resonances of our breaths, balances, rhythms, and touches. In this motional manner we cultivate a relationship through "the foundational qualitative dynamics of movement and their variational possibilities" of "moving in concert" (Sheets-Johnstone, 2014, p. 260). Ground-working Twilight on the hard-packed sand arena becomes "pure depth of support" which I can "know from within, in the stability of [my] own axis of posture" (Lingis, 1994, pp. 123, 124) that tilts and turns with the ground as solid reference. "The ground is there when we assume a posture and support ourselves upright to move" (Lingis, 1998a, p. 14). Ground-working, and "the posture that recognizes and is recognized" (Lingis, 1996, p. 53), puts me in sync with Twilight. She transitions from an extended to a more contracted trot that is called in Dressage a working trot. I feel myself more grounded still. "Every step inaugurates a gait; every displacement a gesture" (Lingis, 1998a, p. 36). Twilight holds the trot while circling the arena. Her ears perk forward, her body bends on the circle rather than leaning in as she did before. She spirals around me as I draw her close and then step again in front to have her turn sweepingly and flowingly in a counter direction. I summon my energies, bringing up life in myself, and in this very moment see Twilight spring forward into an exquisitely collected canter. "It is with forces, welling up in oneself, that life confronts and opposes, but thereby incites, other forces" (Lingis, 1994, p. 51). Yet, rather than confrontation, I feel now a communion of forces, a synergy, that is of the nature of a "sensuous accord" (p. 125).

I am followed by Twilight out of the arena. There is no line connecting us other than the connection felt in the quiet closeness of our walk. Twilight is right on my shoulder as we pass Valentino and head into the paddock with Joey, Emily, and the llamas. She remains close. Stays soft. We stop, stand, and hold this moment of repose. Twilight stretches her neck and head to reach an itch on her sweaty, dusty flanks. She scuffs the ground. There is a bare patch of earth where we are standing. She scuffs the ground a little more with her front hoofs before kneeling down and dropping all her weight. She rolls side to side, caking the dirt on her sweaty coat before springing to her feet and shaking off as much as she can. Is there enjoyment for Twilight in the groundwork we have done together in the sand arena, as there appears to be enjoyment in her rolling on the dusty ground? Lingis (1994) writes of "the gratuitous and excess energies that seek release in exultation" (p. 127) and tells us that "[e]very enjoyment is a death....a dissolution into the beginningless, endless, and fathomless plenum of the elemental" (p. 127). For Twilight, for me, and for us, there is such enjoyment in working together and then simply being together. We each become softer, more grounded, more elementally in tune with one another.

I feel for the affects and look for the effects that this time together with Twilight has on the interconnected, enmeshed critter community. Twilight, who has run riot with the miniatures such that little Joey and Emily cower in corners of the open paddocks or look for refuge in the gardens, is the same Twilight who grieved for days in the spot where Lily the old rescue racehorse is now buried. She is the horse with whom can be experienced in motion, even amid the commotions of this critter community, in the mimic interplay of arena groundwork, a vital contact wherein the "sense of exclusive distinctness as a human [and a horse] dissolves" (Lingis, 2014, p. 57). The soft connection that results appears to soften Twilight's behavior with the other critters. The vital "sensory-motor powers" (Lingis, 1998a, p. 34) expressed in ground-working Twilight are a materialization of the forces of life that bind a critter community together. I feel and imagine Twilight feeling it too: 
How good it is to be alive! The goodness one bespeaks is a goodness one feels, within, in the feeling of excess energy, energy to waste, that is affecting itself and intensifying itself with each dance step one makes in the pas de deux that the dawn is choreographing. (Lingis, 1994, p. 53)

The bodily kinship realized with Twilight that, in turn, affects her interactions with the other farm critters, can intensify, too, in wider relations. Getting in sync with Twilight through postural, positional, gestural means, feeling for the ever-shifting synergies of attuned responsiveness, and lingering in the softened connection that ensues from our time together, can become the choreographic elements of a vivifying eco-pedagogy with other critters, and with those of a human kind as well. We may find that even "more formal, institutionalized representations of pedagogy" can be reanimated through bodily kinships forged within wider, wilder ecologies (Smith, 2014, p. 233; also Smith and LaRochelle, 2018 in press) and, in this interactional, eco-logical endeavor, come to appreciate the motional affordances of an otherwise threatened critter community.

\section{Motional Affordances}

Sasha has been missing for a number of days. We search the most likely places she may be hiding, including the barn area where she and Joey would often dally. The mystery is solved when we discover her maggot-ridden carcass wedged under the floorboards of the chicken coop. There are no signs of forced entry, no burrows underneath the coop, no discernible stretching of the chickenwire enclosure. Immediate suspects come to mind - coyotes, raccoons, weasels, and minks. Precautions need to be taken to ensure there is no further predation. The owner fortifies the coop with more chicken wire. Gaps between the sides and the roof are filled. A trench is dug around the coop and filled with rock and gravel. For the next few evenings the chickens, ducks, and quail are gathered together and sealed securely within the confines of the coop.

It is barely a week after Sasha's body is found that there is the grim discovery of murder and mayhem in the chicken coop. A predator has killed Stanley the Rooster, Stella the hen, along with four of the Indian Runner ducks. Their necks have puncture marks in what looks most likely an attack by a weasel or a mink. Raccoons would surely eat the flesh, as would coyotes, and they would, because of their size, have certainly left clear evidence of forced entry. Regardless, the devastating sight of this carnage has the owner wonder how she might have better protected these critters. Had she, in well-intentioned efforts to make the chicken coop as secure as possible, and in so restricting the flee and flight motions of Stanley, Stella and the Indian Runner ducks, inadvertently contributed to their deaths?

Critter communities, like human communities, can be subject to dire ruptures through heinous acts of predation. The deaths of the chickens and ducks likewise constitute a "catastrophic time" (Lingis, 2000, pp. 117-137). By the same token, protecting critter communities from natural predators need not mean applying the security systems of a gated community that would deny the very motional affordances of ongoing communal living. In fact, what seems most crucial is to preserve the "imperative force" (Lingis, 1994, p. 176; c.f. Lingis, 1998a) underlying the communities of those who may otherwise have nothing in common. In the face of death, we can discover an affinity for one another that is more than our shared mortality. We realize there are motional affordances that keep us alive and that we hold dear for others. Lingis (1994) tells us that: "Community forms in a movement by which one exposes oneself to the other, to forces and powers outside oneself, to death and to others who die" (Lingis, 1994, p. 12). Community is also 
cultivated for the living and by the living in the specific ways in which we move and allow others to move so there can be the plenum release of their and our vital forces and powers. Death is a limit condition that has us consider what more we might do in life, not just to protect other living beings, but to have them flourish in the fuller exercise of their motional identities.

The owner's daughter wraps the remaining Indian Runner duck in a towel. The mink has attacked it as well and left this duck clinging to life. It is unable to walk and lies limply with its neck drooping sideways. Might it not be better to put the duck out of its misery? The owner's daughter will not hear of it and cradles the duck in a towel. She spoons it watery Mask feed over the coming days. She douses the duck under the hose tap and carefully lays her in the nest of rags she has built so the duck can dry in the sunshine. There is some consolation, Lingis (1998a) writes, "in our hand moved by tenderness over the transient surface of things; it is not a consolation for our mortality but an accompaniment of things in their transience" (p. 162).

The alien suffering does not extend at a viewing distance, but afflicts my sensibility immediately. It is felt in my eyes whose direction is confounded, whose focus softens, whose glance turns down in respect. It is felt in my hand that extends to clasp the hand [or paw, or wing] of another as a manipulatable limb, but whose grip loosens under the sense of a sensitivity that touches me. (Lingis, 1994, p. 30)

The duck slowly recovers. It flutters and flaps its wings, teetering, tottering in trying to regain her feet. The owner's daughter assists her up. The duck falls face forward. She flops, flutters, flaps, and eventually stays upright. Her waddle is uncertain at first. Before long the duck is again up and running - an Indian Runner duck.

David Orr (2009) wrote that "we are bound together in the community of life, one and indivisible." We are also bound together in a "community in death" (Lingis, 1994, p. 157) since it is at the limits of our capacity to control and manage the lives of others, and to keep them fully safe and secure, that we may have our most compelling impressions of the movements of life. The will to live is the will to move. It is the integration of "one's sensory-motor powers in such a way that one can advance comprehensively into nature, into the practicable field, into the social order" (Lingis, 1994, p. 19). In the face of death, the duck is helped to regain its life-affirming "senorymotor powers" and to rejoin the community of critters.

A trap is set for the mink. It is the trade-marked, Havahart Animal Trap, a rectangular cage made of wire mesh with doors at either end that, once spring-loaded, will snap shut when the animal takes meat placed inside. The trap is positioned near the chicken coop and right on a path we surmise the mink must have taken when approaching from the drainage ditch at the side of the property. We wait. The night passes uneventfully. The property owner checks the bait in the morning. It is untouched. A second night passes. She again freshens the bait and we wait again. The following morning there is a snarling, scratching, brown-coated mink inside the Havahart Animal Trap. The captured mink looks wilder than any recent escapee from a local fur farm. We take it into the woods for release, but far enough that it will not return and deep enough that it will not have access to other farms where it could again wreak vampiric havoc. The trap is unloaded from the car, laid on the ground, and the cage door opened. The mink scurries to freedom. It bounds into the woods and disappears in a flash into the thicket of Cedar and Hemlock. Have we done the right thing? The mink cannot live with the community of farm critters being cultivated through symbiotic relations and bodily kinships. Yet it surely has a right to live in a wider ecology where it is afforded its own vital, motional powers. 
Pathic communities of those who ostensibly have nothing in common are not overly protected ones but communities in which the diversity of life, and the occasions of death, are afforded their due motions. While great due diligence and a very high standard of care are required of those holding, say, leadership, therapeutic, and especially pedagogical responsibilities for children (Saevi, 2015), the preservation of vital, motional powers noted in critter communities is no less important. In fact, the "power of pedagogy" (van Manen, 2012, p. 9) may well be exercised most keenly in the motional affordances granted to critters who expose the greatest threat to orderly, domestic, rational, community life. Once again, an eco-pedagogical sensitivity arises for us in due attention given to the motional affordances of the critter community.

\section{Conclusion}

Rather than turning away from rational communities, which is to say, from communities of membership and formal association, a critter community of domesticated farm animals shows some ratios necessarily exist. Symbiotic relations of motional, if not emotional, equivalences build ratios of "trust" (Lingis, 2004). Bodily kinships provide for motional and emotional multiplication without unfortunate "excess" (Lingis, 2016). Motional affordances ward against "abuses" (Lingis, 1995) and instill greater powers of moderation. And then, at the limits of such cultivated community sensibilities, we find predatory interests that are not so much to be held in check as they restored to a more natural balance.

Lingis (2007a) tells us that: "Symbiosis with multiplicities of animals reverts to domestication of them" (p. 119). Yet this domestication need not be destructive of the vital powers of any individual animal. In a similar vein, "communities of informal life" (van Manen, 2016, p. 89) amongst members of our own human species can be cultivated in symbiotic responsiveness, bodily kinships, and with appreciation of the motional affordances that allow individuals to flourish. A community of critters serves, then, as inspiration for other operative communities that carry traces of the rational community while being essentially communities of those for whom there may not be anything evidently held in common. Lingis's community and animal writings, which increasingly seem not to have such different foci after all, provoke us to think in a phenomenological way about how pathic communities can be best cultivated among those of our own kind.

"Let us imagine this community as a corporeal community - a community that is more than an aggregation of bodies. We are an organic community of bodies" (Murungi, 2017, p. 59). Let us imagine this pathic community to be essentially an animated one - a community of organisms with capacities for expressive movement and for moving expressively in response to one another. Let us further imagine this community to be a domestication of the herd, the swarm, the pack, the flock, or the school such that vital powers are retained and cast as symbiotic relations between those who may otherwise appear to have nothing in common. Having nothing, and having it in common (Krell, 2003, p. 11), becomes a provocation to consider afresh the very cultivation of pathic communities founded "in the radical experience that each has of sharing with others the originary affectivity of a single life-force" (Gély, 2012, p. 162) and, furthermore, of pathic communities founded in the radical experience of our animality, which is to say, the experience of "when the 'animal' coincides with a motion or a force within it, in such a way that it is nothing but this force and allows itself to be carried away by it" (Henry, 2008, p. 128). 
Let us start right here, in this "animate consciousness" (Sheets-Johnstone, 2011; Smith, 2014, p. 237), and we may well find that the places of community formation in schools, for instance, may not be the classrooms as much as they are the corridors, playgrounds, playing fields, and gymnasia. It is there that the metamorphic impulse can be given freer rein and where symbiotic relations and bodily kinships can become apparent in playing across gender, age, ethnicity, and physical capability lines. While adult responsiveness to children and youth in schools certainly needs to be mindful of their care and projection, and arguably be much more mindful than the care and protection of domesticated farm animals, it is the exercise of metamorphic motions, life forces, and vital powers that constitutes vibrant, pathic communities. We ought neither gloss over these "intermediary powers" nor relegate them to an animistic, tribal past (Biesta, 2004, p. 312). The critter community shows both the determinants and affordances, the limits as well as the possibilities, of cultivating pathic communities in schools and universities, suburban neighborhoods and inner city cores, at home and away, and wherever and whenever we find ourselves with others. For if domesticated animals can not just get along but actually be enlivened in one another's company, then what more might we expect of ourselves as human beings with such vital powers of community affiliation?

\section{References}

Biesta, G. (2004). The community of those who have nothing in common: Education and the language of responsibility. Interchange, 35(3), 307-324.

Churchill, S.D. (2006). Encountering the Animal Other: Reflections on

Moments of Empathic Seeing. Indo-Pacific Journal of Phenomenology, 6: sup1, 1-13, DOI: $10.1080 / 20797222.2006 .11433929$

Deleuze, G., \& Guattari, F. (1987). A thousand plateaus: Capitalism and Schizophrenia (B. Massumi, Trans.). Minneapolis: University of Minnesota Press.

Gély, R. (2012). Towards a radical phenomenology of social life: Reflections from the work of Michel Henry. In J. Hanson \& M.R. Kelly (Eds.), Michel Henry: The affects of thought (154-177). London: Bloomsbury..

Haraway, D. (2003). The Companion Species Manifesto. Dogs, People, and Significant Otherness. Chicago: Prickly Paradigm Press.

Haraway, D. (2008). When Species Meet. Minneapolis: University of Minnesota Press.

Henry, M. (2008). Material phenomenology (S. Davidson, Trans.). New York: Fordham University Press. 
Henry, M. (2015). Incarnation: A philosophy of flesh (K. Hefty, Trans.). Evanston, Ill: Northwestern University Press.

Krell, D. F. (2003). Far from the pallid float. In A. E. Hooke \& W. F. Fuchs (Eds.), Encounters with Alphonso Lingis (3-18). Lanham, Maryland: Lexington Books.

Lingis, A. (1994). The community of those who have nothing in common. Bloomington: Indiana University Press.

Lingis, A. (1995). Abuses. Berkeley: University of California Press.

Lingis, A. (1996). Sensation: Intelligibility in sensibility. New Jersey: Humanities Press.

Lingis, A. (1998a). The imperative. Bloomington, IND: Indiana University Press.

Lingis, A. (1998b). Animal bodies, Discourse, 20(3), 194-203.

Lingis, A. (2000). Dangerous emotions. Berkeley: University of California Press.

Lingis, A. (2001) Ecological Consciousness: Reflections on Hominids and Other Thinking Animals, Critical Horizons, 2(2), 283-300.

Lingis, A. (2003). Animal body, inhuman face. In C. Wolfe (Ed.), Zoontologies: The question of the animal (165-182). Minneapolis: University of Minnesota Press.

Lingis, A. (2004). Trust. Minneapolis: University of Minnesota Press.

Lingis, A. (2005). Contact, Janus Head, 8(2), 439-454.

Lingis, A. (2007a). Subjectification. Continental Philosophy Review, 4, 113-123.

DOI 10.1007/s11007-007-9054-5

Lingis, A. (2007b). The first person singular. Evanston, Illinois: Northwestern University Press.

Lingis, A. (2010). The environment: A critical appreciation of Levinas's analysis of Existence and Existents. Levinas Studies, 5, 65-81.

Lingis, A. (2011a). Outside. Social Text 106, 29(1), 37-42. DOI 10.1215/01642472-1210256

Lingis, A. (2011b). Violence and Splendor. Evanston, Illinois: Northwestern University Press.

Lingis, A. (2014). Faces. Denver Quarterly, 48(4), 53-60.

Lingis, A. (2016). Aconcagua. In R. C. Wheeler (Ed.), Passion in philosophy: Essays in honor of Alphonso Lingis (3-16). Lanham, Maryland: Lexington Books.

McLane, J. (2003). Encounter the world, keep a close eye. In A. E. Hooke \& W. F. Fuchs (Eds.), Encounters with Alphonso Lingis (51-62). Lanham, Maryland: Lexington Books. 
Murungi, J. (2017). On Alphonso Lingis's $80^{\text {th }}$ birthday - A philosophical journey: From nowhere to nowhere. In R. C. Wheeler (Ed), Passion in philosophy: Essays in honor of Alphonso Lingis (49-64). Lanham, Maryland: Lexington Books.

Neimans, A. (2007). Becoming Grizzly: Body molecularity and the animal that becomes. PhaenEx: Journal of Existential and Phenomenological Theory and Culture, 2(2), 279-308.

Orr, D. (2009). The intelligence of ecological design. Centre for Ecoliteracy. Reprint of an essay $\begin{array}{llll}\text { originally in } & \text { Resurgence, } & \text { September/October }\end{array}$ https://www.ecoliteracy.org/article/intelligence-ecological-design\#

Saevi, T. (2015). Learning and pedagogic relations. In D. Scott \& E. Hargreaves (Eds.), The SAGE handbook of learning (342-352). London: SAGE Publications,. DOI: http://dx.doi.org/10.4135/9781473915213

Sheets-Johnstone, M. (2014). Animation: Analyses, Elaborations, and Implications. Husserl Studies, 30, 247-268. DOI 10.1007/s10743-014-9156-y

Smith, S. J. (2014). A pedagogy of vital contact. Journal of Dance and Somatic Practices, 6 (2), 233-246.

Smith, S. J. (2017). The vitality of humanimality: From the perspective of life phenomenology. Phenomenology \& Practice, 11(1), 72-88.

Smith, S. J., \& LaRochelle (2019 in press). Being with horses as a practice of the self-with-others: A case of getting a FEEL for teaching. In O. Gunnlaugson, E. Sarath, H. Bai \& C. Scott (Eds.), The intersubjective turn in contemplative education: Shared approaches for contemplative learning \& inquiry across disciplines (59-71). New York: SUNY Press.

Sparrow, T. (2007). Bodies in transit: The plastic subject of Alphonso Lingis. Janus Head, 10(1), 99-122.

van Manen, M. (2012). The call of pedagogy as the call of contact. Phenomenology \& Practice, $6(2), 8-34$.

van Manen, M. (2016). Pedagogical tact: Knowing what to do when you don't know what to do. New York: Routledge.

Welten, R. (2016). Community from the perspective of life. Analecta Hermeneutica, 8, 130-148.

Zournazi, M. (2003). Foreign bodies: Interview with Alphonso Lingis. In A. E. Hooke \& W. F. Fuchs (Eds.), Encounters with Alphonso Lingis (83-98). Lanham, Maryland: Lexington Books. 